\title{
Chia, Quinoa, and Their Coproducts as Potential Antioxidants for the Meat Industry
}

\author{
Juana Fernández-López ${ }^{\mathbb{D}}$, Manuel Viuda-Martos ${ }^{\mathbb{D}}$, María Estrella Sayas-Barberá,

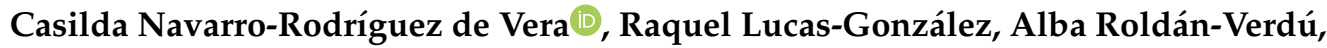 \\ Carmen Botella-Martínez and Jose Angel Pérez-Alvarez *(D)
}

IPOA Research Group, Agro-Food Technology Department, Higher Polytechnic School of Orihuela, Miguel Hernández University, Orihuela, 03312-Alicante, Spain; j.fernandez@umh.es (J.F.-L.); mviuda@umh.es (M.V.-M.); estrella.sayas@umh.es (M.E.S.-B.); casilda.navarro@umh.es (C.N.-R.d.V.); raquel.lucasg@umh.es (R.L.-G.); alba.roldan1880@gmail.com (A.R.-V.); c.botella@umh.es (C.B.-M.)

* Correspondence: ja.perez@goumh.umh.es; Tel.: +94-96-674-9739

Received: 16 September 2020; Accepted: 8 October 2020; Published: 14 October 2020

\begin{abstract}
Chia and quinoa have gained popularity among consumers worldwide due to the wide variety of nutrients but also to the bioactive compounds that they contain. Lately, their processing has generated different coproducts (non-commercial grains, flour, partially deoiled flour, rich-fiber fraction, and oil, among others), which could be reincorporated to the food chain with important technological properties, antioxidant activity included. Both sets of ingredients have been revealed a great technological potential for meat product development and innovation, taking into account that oxidation is one of the main reactions responsible for their deterioration and shelf life reduction. This review focuses on the antioxidant compounds of chia and quinoa coproducts and on the strategies used to add them to meat products highlighting their effect on the lipid oxidation control. Apart from the different ways in which quinoa and chia can be incorporated into meat products and their antioxidant properties, innovative approaches for increasing this antioxidant effect and counteracting any negative alterations they may cause will be discussed.
\end{abstract}

Keywords: chia; quinoa; antioxidants; meat products; lipid oxidation

\section{Introduction}

Chia (Salvia hispanica L.) and quinoa (Chenopodium quinoa Willd) seeds have been consumed in their respective country of origin for centuries (Andean countries for quinoa and Mexico and Guatemala for chia); however, currently they have gained a renewed relevance in developed countries due to their excellent nutritional value and also to the large variety of bioactive compounds that they contain [1-4]. In addition, both seeds have demonstrated interesting technological properties in food processing that make them not only suitable for their direct consumption but also for their application as ingredients in different foods [5-9]. Due to the boom in the consumption and commercialization of chia and quinoa related food products, which includes not only quinoa and chia seeds but also different types of foods in which both can be applied, in the form of flours (obtained by a dry or wet-milling process), bran, enriched fractions (fiber, protein, and starch), oil, mucilage, partially deoiled flour, etc., depending on the aim of the food industry, a wide range of coproducts are been generated [7,9-11] (Figure 1). Chia and quinoa (seeds or flour) can be added or mixed into bread, biscuits, pasta, snacks, cakes, emulsified meat products, etc., as supplements or as substitutes for eggs and fat. Quinoa flour has also been used as binder or extender in meat products. Fiber, protein, and starch-rich fractions from quinoa can be used to increase the content of these nutrients in several foods. Chia mucilage may be used as a foam stabilizer, emulsifier, or binder in the food industry and also as a functional 
coating with improved functional properties. Chia oil can be used to replace animal fat in foods with an increase in their nutritional value. Partially deoiled chia flour has been used as a source of dietary fiber in meat products. All of them are examples about the application of some of these coproducts in the food industry $[5,9,11-14]$.

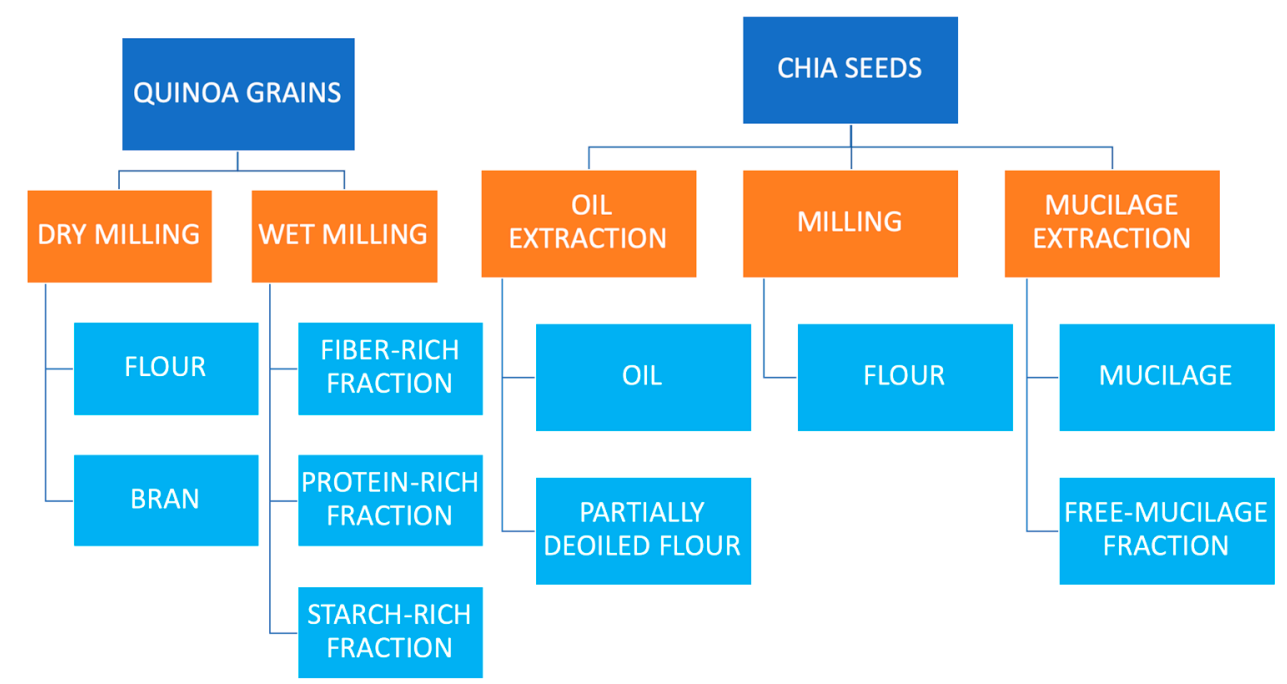

Figure 1. Main coproducts obtained from quinoa and chia processing.

Nutritionally, quinoa stands out for its fiber content $(5-11 \%)$, starch $(52-74 \%$ being rich in amylopectin), proteins (13-17\%) with the presence of essential amino acids (methionine and lysine but also a high concentration of tryptophan, usually the second limiting amino acid in cereals), and fatty acids (2-9\% oil with $90 \%$ unsaturated fatty acids of which $50-56 \%$ correspond to linoleic acid omega-6, $22-25 \%$ to oleic acid omega-9, and 5-7\% to linolenic acid omega-3), absence of gluten, and adequate levels of key micronutrients, including minerals (calcium, magnesium, iron, potassium, phosphorus, manganese, zinc, copper, and sodium) and vitamins (vitamin B complex, E, and C) [8,15-17]. Quinoa also contains bioactive constituents, such as carotenoids, tocopherols, polyphenols, and betalains, which are responsible for protecting the plant against adverse climatic conditions and are highly correlated with its antioxidant activity $[4,18,19]$. Regarding chia, it stands out also for its fiber content (18-30\% being soluble dietary fiber $7-15 \%)$, proteins of high biological value (15-25\%), and it is considered a natural source of omega- 3 ( $\alpha$-linolenic acid up to $68 \%$ of fatty acid content) and omega- 6 fatty acids (linoleic acid 19\%) [20-22]. It also contains bioactive compounds such as tocopherols, polyphenols, vitamins (mainly vitamin B1, B2, and niacin), and carotenoids [23-25].

Most of the bioactive compounds in quinoa and chia seeds are related to their antioxidant activity. Antioxidants are substances that protect cells against oxidative damage caused by excess reactive oxygen species. Oxidative stress, which releases free oxygen radicals in the body, has been implicated in several disorders, including chronic-degenerative diseases such as cardiovascular diseases, cataracts, diabetes, Alzheimer's disease, cancers, and rheumatism [26-29]. It is well known that bioactive compounds in vegetal foods can act as antioxidants, protecting the cells. On the other hand, the addition of chia or/and quinoa in foods enables that their antioxidant compounds could prevent food deterioration caused by lipid oxidation. Lipid oxidation in foods (oils, fats, and other fat-containing foods) is responsible for the development of primary and secondary oxidation products, reduction in nutritional quality, as well as changes in flavor [30,31], which can precipitate health hazards and economic losses in terms of inferior product quality $[32,33]$.

Specifically, in meat and meat products, lipid oxidation is the major cause of quality deterioration, affecting either the stored triglycerides or the tissue phospholipids. In addition, ferric heme pigments have been implicated as the major pro-oxidants in meat lipid oxidation, being both reactions, pigment, and lipid oxidation, interrelated [34,35]. Nonheme iron may also function as prooxidant in meat [36]. 
Additionally, even some processing operations during meat products manufacturing (grounding, sodium chloride addition, and cooking, among others) contribute to accelerating the oxidation of the triglycerides $[37,38]$. For these reasons, antioxidants (synthetics) have been usually added to fresh and processed meat and meat products to prevent lipid oxidation, retard the development of off-flavors, and improve color stability by scavenging chain-carrying peroxyl radicals or suppressing the formation of free radicals [39]. The most widely used synthetic antioxidants in the meat industry, butylated hydroxyanisole (BHA) and butylated hydroxytoluene (BHT), are quite volatile and decompose easily at high temperatures [40]. There are serious concerns about the safety and toxicity of BHA, BHT and tert-butylhydroxyquinone (TBHQ) related to their metabolism and possible absorption and accumulation in body organs and tissues [41]. In response to the claims that synthetic antioxidants have the potential to cause toxicological effects and consumers increased interest in purchasing natural products, the meat industry has been seeking sources of natural antioxidants [33]. Most of these natural antioxidants came from fruits, spices or other plant-based ingredients (which may be found in any plant part, such as grains, fruits, nuts, seeds, leaves, roots, arils, and barks) and they owe their antioxidant activity mainly to their bioactive compounds (polyphenols, anthocyanins, tocopherols, and carotenoids, among others) [42,43].

Considering that, in this review, we summarize and discuss recent advances about the composition and identification of bioactive compounds with antioxidant properties in chia and quinoa edible grains and their coproducts. It is also aimed at exploring the effect of the addition of chia, quinoa or their coproducts on the development of the lipid oxidation in chia and quinoa related meat products due to the antioxidant properties attributed to these bioactive compounds.

\section{Antioxidants Compounds in Chia, Quinoa, and Their Coproducts}

There are a lot of works about the bioactive compounds in chia and quinoa seeds that confirm that they contain a rich pool of natural antioxidants such as tocopherols, phytosterols, carotenoids, and phenolic compounds $[4,8,18,44-49]$, which could protect consumers against many diseases and also promote beneficial effects on human health [50].

In both cases (chia and quinoa), it has been reported that climatic conditions and geographical location of growing have a great influence on the chemical composition of the seeds $[23,47,51-56]$. In addition to the differences in the composition of the several bioactive compounds, it is necessary to add another variation factor such as the extraction procedure used (solvent, procedure, and extraction time) since it is a critical process for some matrices, particularly when there may be insoluble components with antioxidant capacity, which lead to underestimated these values in some cases [57-59]. Recently, important differences between authors have also been detected depending on the application or not of a hydrolysis treatment, which can be used for different purposes depending on when it is applied; if it is used during the extraction process, it can help to elucidate the amount of the phenolic compounds bounded to other structures in the cell wall, which are not easily extracted, but if it is used to the extract prepared it can simplify the sample and make easier the identification step [23,60]. In addition, depending on the coproduct, also important differences in the content on bioactive compounds could be expected. All these variability factors make it difficult, in some cases, to compare data reported by different authors, however, similar trends can be observed in most of them (Table 1). 
Table 1. Total phenolic content and antioxidant activity of chia, quinoa, and their coproducts.

\begin{tabular}{|c|c|c|c|c|c|c|}
\hline & \multirow[t]{2}{*}{ Origin } & \multirow{2}{*}{$\begin{array}{c}\text { Total Phenol } \\
\text { Content (TPC) } \\
\text { (mg GAE/g) }\end{array}$} & \multicolumn{2}{|c|}{ Antioxidant Activity } & \multirow{2}{*}{$\begin{array}{c}\text { Extraction } \\
\text { Protocol }\end{array}$} & \multirow[t]{2}{*}{ References } \\
\hline & & & $\begin{array}{c}\text { DPPH } \\
(\mathrm{mg} \text { TE/g) }\end{array}$ & $\begin{array}{c}\text { FRAP } \\
(\mathrm{mg} \text { TE/g) }\end{array}$ & & \\
\hline \multicolumn{7}{|l|}{ QUINOA } \\
\hline $\begin{array}{c}\text { seeds } \\
\text { (white, red, and black) }\end{array}$ & Bolivia & $5.0-6.6$ & 3.4 & 2.7 & $\begin{array}{c}\text { double extraction } \\
\text { (methanol/water and } \\
\text { acetone/water) }\end{array}$ & Ballester-Sánchez et al. [12] \\
\hline $\begin{array}{l}\text { seeds } \\
\text { (colored) }\end{array}$ & Peru & $1.2-3.4$ & - & - & $\begin{array}{l}\text { double extraction } \\
\text { (methanol/water and } \\
\text { acetone/water) }\end{array}$ & Abderrahim et al. [26] \\
\hline $\begin{array}{c}\text { seeds } \\
\text { (red and yellow) }\end{array}$ & - & $1.4-2.1$ & - & $6-9$ & $\begin{array}{l}\text { double extraction } \\
\text { (methanol/water and } \\
\text { acetone/water) }\end{array}$ & Brend et al. [61] \\
\hline seeds & Bolivia & 3.8 & 9.7 & - & $\begin{array}{l}\text { double extraction } \\
\text { (methanol/water and } \\
\text { acetone/water) }\end{array}$ & Pasko et al. [62] \\
\hline $\begin{array}{c}\text { seeds } \\
\text { (white and colored) }\end{array}$ & Bolivia and Perú & $3.9-4.2$ & $1.9-5.0$ & $2.4-4.6$ & $\begin{array}{c}\text { double extraction } \\
\text { (methanol/water and } \\
\text { acetone/water) }\end{array}$ & Pellegrini et al. [4] \\
\hline $\begin{array}{l}\text { seeds } \\
\text { (red) }\end{array}$ & Bolivia & 4.9 & 6.0 & - & $\begin{array}{l}\text { double extraction } \\
\text { (methanol/water and } \\
\text { acetone/water) }\end{array}$ & Ballester Sánchez et al. [10] \\
\hline $\begin{array}{c}\text { seeds } \\
\text { (white, red, and black) }\end{array}$ & $\begin{array}{l}\text { Andean Region and } \\
\text { Canada }\end{array}$ & $2.0-5.2$ & $1.3-2.8$ & $2.0-8.8$ & $\begin{array}{l}\text { one extraction } \\
\text { (acetone/water) } \\
\text { double extraction }\end{array}$ & Tang et al. [18] \\
\hline seeds & Peru & $0.8-3.4$ & $1.6-2.2$ & - & $\begin{array}{l}\text { (ethanol/water and } \\
\text { methanol/water) }\end{array}$ & Valencia et al. [63] \\
\hline $\begin{array}{c}\text { seeds } \\
\text { (white, red, and black) }\end{array}$ & Bolivia & $5.1-6.1$ & $1.8-3.5$ & - & $\begin{array}{l}\text { double extraction } \\
\text { (methanol/water) }\end{array}$ & Liu et al. [49] \\
\hline $\begin{array}{l}\text { seeds } \\
\text { (yellow) }\end{array}$ & $\begin{array}{l}\text { Poland, Denmark, } \\
\text { Chile and Argentine }\end{array}$ & $7.1-10.6$ & - & - & $\begin{array}{l}\text { triple extraction } \\
\text { (methanol/water, } \\
\text { methanol/water and } \\
\text { acetone/water) }\end{array}$ & Sobota et al. [64] \\
\hline seeds & Peru & $1.4-1.9$ & $0.1-2.4$ & - & $\begin{array}{l}\text { one extraction } \\
\text { (ethanol/water) }\end{array}$ & $\begin{array}{c}\text { Repo-Carrasco-Valencia et al. [65] } \\
\text { Repo-Carrasco-Valencia and Celada [66] }\end{array}$ \\
\hline
\end{tabular}


Table 1. Cont

\begin{tabular}{|c|c|c|c|c|c|c|}
\hline & \multirow[t]{2}{*}{ Origin } & \multirow{2}{*}{$\begin{array}{c}\text { Total Phenol } \\
\text { Content (TPC) }\end{array}$} & \multicolumn{2}{|c|}{ Antioxidant Activity } & \multirow{2}{*}{$\begin{array}{c}\text { Extraction } \\
\text { Protocol }\end{array}$} & \multirow[t]{2}{*}{ References } \\
\hline & & & $\begin{array}{c}\text { DPPH } \\
\text { (mg TE/g) }\end{array}$ & $\begin{array}{c}\text { FRAP } \\
(\mathrm{mg} \text { TE/g) }\end{array}$ & & \\
\hline $\begin{array}{c}\text { seeds } \\
\text { (white, red, and black) }\end{array}$ & Peru & $0.6-1.0$ & $0.5-1.5$ & - & $\begin{array}{l}\text { one extraction } \\
\text { (ethanol/water) }\end{array}$ & Díaz-Valencia et al. [67] \\
\hline seeds & Iran & $0.2-0.4$ & - & - & $\begin{array}{l}\text { one extraction } \\
\text { (ethanol/water) }\end{array}$ & Farajzadeh et al. [68] \\
\hline seeds & Ecuador and Peru & $7.7-8.6$ & $0.7-1.7$ & $0.7-2.2$ & $\begin{array}{l}\text { triple extraction } \\
\text { (methanol/water) }\end{array}$ & Dini et al. [48] \\
\hline $\begin{array}{l}\text { flour } \\
\text { (white) }\end{array}$ & Mexico & $1.8-3.2$ & - & - & $\begin{array}{c}\text { one extraction } \\
\text { (methanol/water) }\end{array}$ & Vazquez-Luna et al. [69] \\
\hline $\begin{array}{c}\text { flour } \\
\text { (white) }\end{array}$ & Egypt & 0.2 & - & - & $\begin{array}{l}\text { one extraction } \\
\text { (methanol/water) }\end{array}$ & Sohaimy et al. [70] \\
\hline $\begin{array}{c}\text { flour } \\
\text { (white, red, and black) }\end{array}$ & Peru & $0.6-1.0$ & - & - & $\begin{array}{l}\text { one extraction } \\
\text { (ethanol/water) }\end{array}$ & Aguilar et al. [71] \\
\hline $\begin{array}{c}\text { malted flour } \\
\text { (white, red, and black) }\end{array}$ & Peru & $0.9-1.5$ & - & - & $\begin{array}{l}\text { one extraction } \\
\text { (ethanol/water) }\end{array}$ & Aguilar et al. [71] \\
\hline $\begin{array}{l}\text { fiber-rich fraction by } \\
\text { wet-milling (red) }\end{array}$ & Bolivia & 3.8 & 3.6 & 3.6 & $\begin{array}{c}\text { double extraction } \\
\text { (methanol/water and } \\
\text { acetone/water) }\end{array}$ & Ballester Sánchez et al. [10] \\
\hline $\begin{array}{l}\text { fiber-rich fraction by } \\
\text { dry-milling (red) }\end{array}$ & Bolivia & 6.6 & 5.2 & 6.9 & $\begin{array}{c}\text { double extraction } \\
\text { (methanol/water and } \\
\text { acetone/water) }\end{array}$ & Ballester Sánchez et al. [10] \\
\hline \multicolumn{7}{|l|}{ CHIA } \\
\hline seeds & Bolivia and Peru & 4.1 & 5.6 & 70.1 & $\begin{array}{c}\text { double extraction } \\
\text { (methanol/water and } \\
\text { acetone/water) }\end{array}$ & Fernández-López et al. [22] \\
\hline seeds & Australia & 2.4 & - & - & $\begin{array}{c}\text { ethanol/water } \\
\text { double extraction }\end{array}$ & Ding et al. [21] \\
\hline seeds & Bolivia and Peru & 3.9 & 5.4 & 71.8 & $\begin{array}{c}\text { (methanol/water and } \\
\text { acetone/water) }\end{array}$ & Pellegrini et al. [3] \\
\hline seeds & Bolivia and Chile & 1.2 & - & 18.5 & $\begin{array}{l}\text { double extraction } \\
\text { (methanol/water) }\end{array}$ & Oliveira-Alves et al. [60] \\
\hline seeds & Chile & 0.94 & 109.2 & - & ethanol & Marinelli et al. [47] \\
\hline seeds & Mexico & $0.88-0.92$ & - & - & ethanol & Reyes-Caudillo et al. [23] \\
\hline
\end{tabular}


Table 1. Cont

\begin{tabular}{|c|c|c|c|c|c|c|}
\hline & \multirow[t]{2}{*}{ Origin } & \multirow{2}{*}{$\begin{array}{c}\text { Total Phenol } \\
\text { Content (TPC) }\end{array}$} & \multicolumn{2}{|c|}{ Antioxidant Activity } & \multirow{2}{*}{$\begin{array}{c}\text { Extraction } \\
\text { Protocol }\end{array}$} & \multirow[t]{2}{*}{ References } \\
\hline & & & $\begin{array}{c}\text { DPPH } \\
\text { (mg TE/g) }\end{array}$ & $\begin{array}{c}\text { FRAP } \\
(\mathrm{mg} \text { TE/g) }\end{array}$ & & \\
\hline seeds & Italian & 1.8 & - & - & $\begin{array}{c}\text { acetonitrile/acetic acid } \\
\text { solution }\end{array}$ & Caruso et al. [72] \\
\hline seeds & Mexico & $0.5-0.7$ & - & - & ethanol & Porras-Loaiza et al. [73] \\
\hline seeds & Mexico & 1.64 & - & - & $\begin{array}{c}\text { triple } \\
\text { (methanol/water) }\end{array}$ & Martínez-Cruz and Paredes-López [25] \\
\hline seeds & Argentine & 3.4 & 49.37 & & methanol/water & Tuncil and Celik [74] \\
\hline seeds & Italy & 1.5 & 1.6 & - & $\begin{array}{c}\text { ethanol/water } \\
\text { water/ethanol/acetone }\end{array}$ & Antonini et al. [75] \\
\hline seeds & Brazil & $10.1-60.9$ & $2.5-95.1$ & $5.1-247.6$ & $\begin{array}{c}\text { (alone and different } \\
\text { mixtures) }\end{array}$ & Alcântara et al. [55] \\
\hline flour & Brazil & 4.8 & - & - & $\begin{array}{c}\text { acetonitrile/acetic acid } \\
\text { solution }\end{array}$ & Dick et al. [76] \\
\hline flour & Mexico & 7.9 & - & - & $\begin{array}{c}\text { acetonitrile/acetic acid } \\
\text { solution }\end{array}$ & Dick et al. [76] \\
\hline oil & Bolivia and Chile & 0.02 & - & 0.2 & methanol/water & Oliveira-Alves et al. [60] \\
\hline oil & Japan & 4.9 & $\begin{array}{l}6.1 \mathrm{IC}_{50} \\
(\mathrm{mg} / \mathrm{L})\end{array}$ & - & methanol & Xuan et al. [77] \\
\hline $\begin{array}{l}\text { partially-deioled } \\
\text { flour }\end{array}$ & Bolivia and Chile & 1.1 & - & 17.2 & $\begin{array}{l}\text { double extraction } \\
\text { (methanol/water) }\end{array}$ & Oliveira-Alves et al. [60] \\
\hline $\begin{array}{l}\text { partially-deioled } \\
\text { flour }\end{array}$ & Argentine & 2.2 & - & - & $\begin{array}{l}\text { double extraction } \\
\text { (acetone/water) }\end{array}$ & Aranibar et al. [13] \\
\hline $\begin{array}{l}\text { partially-deioled } \\
\text { flour }\end{array}$ & Bolivia and Peru & 5.0 & 7.0 & 81.0 & $\begin{array}{c}\text { double extraction } \\
\text { (methanol/water and } \\
\text { acetone/water) }\end{array}$ & Fernández-López et al. [22] \\
\hline $\begin{array}{l}\text { partially-deioled } \\
\text { flour }\end{array}$ & Bolivia and Peru & 4.9 & 7.2 & 80.9 & $\begin{array}{c}\text { double extraction } \\
\text { (methanol/water and } \\
\text { acetone/water) }\end{array}$ & Pellegrini et al. [3] \\
\hline
\end{tabular}




\subsection{Chia and Its Coproducts}

In reference to chia seeds, most of the data already reported in the literature show total phenolic content values ranging between 0.5 and $3.9 \mathrm{mg}$ gallic acid equivalents (GAE)/g chia. Da Silva et al. [56] reported a TPC of $0.98 \mathrm{mg} \mathrm{GAE} / \mathrm{g}$ in chia seeds from Brazil, which is in accordance with the amount reported by other authors for chia seeds from Chile $(0.94 \mathrm{mg} \mathrm{GAE} / \mathrm{g}$, [47]; $1.16 \mathrm{mg} \mathrm{GAE} / \mathrm{g}$, [60]), Mexico (0.90 mg GAE/g; [23]), or Bolivia (1.16 mg GAE/g; [60]). Higher TPC values (3.9-4.1 mg GAE/g chia) have been reported by Pellegrini et al. [3] and Fernández-López et al. [22]. Alcântara et al. [55] reported a wide variation range (10.1-60.9 $\mathrm{mg}$ GAE/g chia) in chia seeds from Brazil depending on the solvent used. Controversial results have been reporting regarding the effect of the hydrolysis process; Reyes-Caudillo et al. [23] reported that the acidic hydrolysis did not increase the TPC compared to crude extract of chia seeds, whereas Oliveira-Alves et al. [60] reported a significant increase in hydrolyzed extracts. It is important to highlight that after the extraction of chia oil, only $5 \%$ of TPC was found in chia oil and the rest (95\%) remain in the deoiled chia flour $[3,22,60]$. TPC in chia oil also depend on the oil extraction procedure: Itxaina et al. [78] reported that TPC was significantly higher when the oil was obtained by pressure than by the solvent system. Xuan et al. [79] compared the TPC of 14 edible oils (chia, flax, sunflower, canola, grape, avocado, and sesame, among others) reporting for chia oil one of the lowest values (4.86 mg GAE/g oil; similar to sunflower oil) in comparison with the TPC found in flax (39.2 mg GAE/g oil) or avocado (11.31 mg GAE/g oil) oils. On the other hand, the partially deoiled flour obtained after the extraction of oil from chia seeds has a TPC similar than reported for chia seeds [22].

About the composition of the phenolic compounds in chia seeds, in all cases, different phenolic acids, flavonoids, and tannins have been identified. Figure 2 shows the main antioxidant compounds identified in chia seeds. Rosmarinic acid has been reported as the major compound detected and quantified in chia seeds $[3,22,25,55,60]$ representing approximately $75-90 \%$ of the phenolic acids. Ferulic, caffeic, salicylic, and the protocatechinic acids have also been identified $[3,23,25,46,55]$. The carnosol, a phenolic diterpene, has been identified by Oliviera-Alves et al. [60]. Ding et al. [21] reported that flavonoid content occupied $80.8 \%$ in the polyphenols of chia, being rutin and hesperidin the major components. The flavonols group has been also identified in most of the works, being myricetin, quercetin, and kaempferol (mainly glycosides but also in aglycon forms) the predominant ones [18]. Myricetin was also the second main compound identified by Alcântara et al. [55] representing $88 \%$ of the flavonoids. Pellegrini et al. [3] reported quercetin as the main flavonoid and also detected myricetin and rutin. The isoflavones group has also been mostly identified. Martínez-Cruz and Paredes-López [25] identified daidzin, glycitin, genistin, glycetein, and genistein and proposed the chia seeds as a novel isoflavone source in the human diet. Pellegrini et al. [3] and Fernández-López et al. [22] identified daizdin as the second compound most abundant (followed by quercetin), and genistin, and genistein were also identified. On the contrary, Reyes-Caudillo et al. [23] reported that the anthocyanins group was not detected in Mexican seeds. Ixtaina et al. [45] reported that the major phenolic compounds in chia oil were chlorogenic and caffeic acids, followed by myricetin, quercetin, and kaemferol, being all of them also detected in chia seeds. It is interesting to note that most of the phenolic compounds found in chia are not present in other oilseeds [47,79]. Fernández-López et al. identified, in partially deoiled chia flour, the same 11 compounds (phenolic acids, flavonols, and isoflavones) than in the corresponding chia seeds, although in higher concentrations, which confirms the fact that most of the phenolic compounds remain in this coproduct after the oil extraction. Similar results have been reported for this chia coproduct by Capitani et al. [46]: in this case, the authors did not find differences in the total polyphenolic component concentration between the partially deoiled flours obtained for solvent or pressing oil extraction.

Tocopherols have also found in chia seeds although the concentration and the type (isoform) identified vary depending on growth location and conditions. Da Silva et al. [56] reported in chia seeds from Brazil, an average content of total tocopherols $(\alpha-, \beta-, \gamma-$, and $\delta-)$ of about $8205.6 \mu \mathrm{g} / 100 \mathrm{~g}$, being $\gamma$-tocopherol the predominant isoform (90\% approximately). Capitani et al. [46] reported a 
similar tocopherol concentration in chia grown in Argentina and also in this case the component present in larger amounts was $\gamma$-tocopherol. Controversial results were observed in other studies that used chia grown in Argentina and Guatemala $[45,46]$ since the authors did not detect the presence of $\beta$-tocopherol. Itxaina et al. [45] reported approximately $300 \mathrm{mg}$ of tocopherols $/ \mathrm{kg}$ in the chia oil obtained by solvent and lower amounts $(238 \mathrm{mg} / \mathrm{kg}$ ) when it was obtained by pressing, which is in accordance with that reported by Guiotto et al. [78]. Capitani et al. [46] also detected tocopherols in partially deoiled flours obtained by pressing and solvent extraction being $\gamma$-tocopherol the main component (approximately 95\%) in both cases.

Carotenoids are minor phytochemicals detected in chia seeds and only a few studies have been developed to identify them, so it could be said that chia carotenoid composition is still unknown. Da Silva et al. [56] reported a total amount of carotenoids of $57 \mu \mathrm{g} / 100 \mathrm{~g}$ in chia seeds from Brazil, being the zeaxanthin identified as the main compound. Dabrowski et al. [80] reported that ca. 2/3 constitutes lutein, with and approximately $30 \%$ share of $\beta$-carotene and small amounts of 9 -cis- $\beta$-carotene.
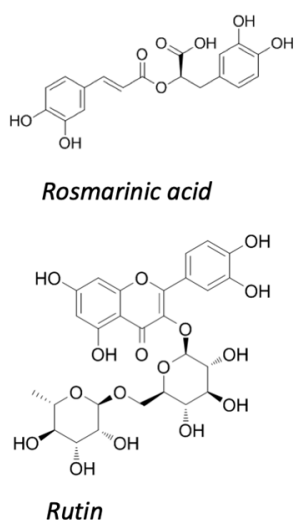

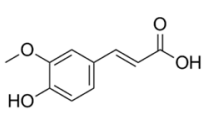

Ferulic acid

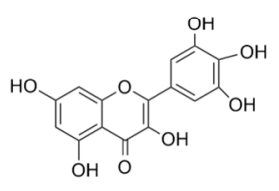

Myricetin

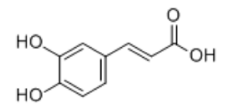

Cafeic acid

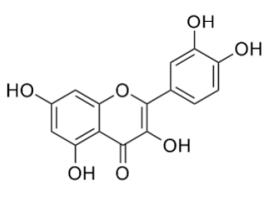

Quercetin

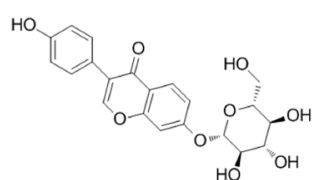

Daizdin

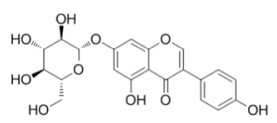

Genistin

Figure 2. Chemical structure of the main polyphenolic compounds identified in chia seeds.

\subsection{Quinoa and Its Coproducts}

Quinoa grains also are considered a good source of various bioactive compounds with antioxidant properties being the phenolic compounds the most important and studied although recently, several carotenoids and betalains, mainly present in colored quinoas, have also been highlighted due to their antioxidant properties. All these compounds contribute to the antioxidant effect of quinoa grains. Figure 3 shows some of the principal antioxidant compounds identified in quinoa seeds. Polyphenols are natural organic chemicals with large multiples of phenol structural units. The TPC reported in quinoa grains ranged between 0.2 and $10.6 \mathrm{mg} \mathrm{GAE} / \mathrm{g}$ quinoa with significant differences depending (in addition to the other variation factors previously discussed) on their color: darker quinoa seeds (such as red and black quinoas) showed higher TPC than white varieties $[4,18,48,49,67]$. Not only the TPC was suggested to differ according to the color of quinoa grains, but also the phenolic profiles and their antioxidant activity. Recently, several authors have reported that the malting process increases the amount of phenolic compounds (up to $49 \%$ comparing to the initial content before malting) in quinoa flour [71]. These authors also reported that this increase was higher in flour from colored quinoas (red and black) than from the white ones. Ballester-Sánchez et al. [10] determined the TPC (both polyphenol fractions, extractable and hydrolysable) in red quinoa seeds and in the fiber-rich fractions obtained by the dry and wet-milling process, reporting values for the extractable fraction (the most frequently reported by authors) of $4.9 \mathrm{mg} \mathrm{GAE} / \mathrm{g}$ for the whole seeds and $3.8 \mathrm{mg} \mathrm{GAE} / \mathrm{g}$ and $6.6 \mathrm{mg} \mathrm{GAE} / \mathrm{g}$ for the fractions from wet and dry-milling, respectively. As can be seen, the wet-milling fiber showed lower values in the extractable polyphenol fraction than the whole seeds, whereas they were the same in the case of the fiber fraction from dry-milling. These results were expected taking into account that the extractable polyphenol fraction consists of polyphenols water soluble and can therefore be leached in the steeping water used during the wet-milling process. These values were significantly 
increased when the hydrolysable fraction was assessed, reporting values of 34, 77, and $83 \mathrm{mg} \mathrm{GAE} / \mathrm{g}$ for the whole seeds, dry-milling, and wet-milling fractions, respectively. It is important to note that in both fiber-rich fractions the hydrolysable polyphenol fraction was clearly enriched in comparison with the quinoa seeds (around 2.5 fold). This result also was expected given that this fraction (hydrolysable polyphenols) represents the polyphenols bound to cell wall macromolecules and to dietary fiber. The most abundant polyphenols in quinoa are phenolic acids and flavonoids [2,18,65]. Eleven kinds of phenolic acids have been detected in quinoa samples (protocatechuic, $p$-hydroxybenzoic, vanillic, syringic, $P$-coumaric, ferulic, sinapic and isoferulic, cholorogenic, rosmarinic, and caffeic acids) with their total amount ranging from 56 to $95 \mu \mathrm{g} / \mathrm{g}[4,18,49,65,81]$. Phenolic acids also exist in the form of free and bound and it has reported significant differences in the content of bound phenolics between different quinoa varieties, while their content of free phenolics showed relatively small differences $[26,82,83]$. Ferulic acid and its derivatives were the predominant phenolics in the bound form to be present in quinoa seeds $[4,81,84]$. It is relevant because bound phenolics of quinoa have shown a higher ability to scavenge the 2,2-diphenyl-1-picrilhidrazilo (DPPH) and the 2,2-azino-bis(3-ethylbenzothiazoline-6-sulfonic acid) (ABTS) free radicals than the free phenolics $[49,82]$.

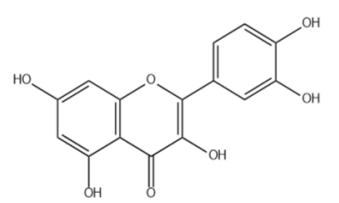

Quercetin

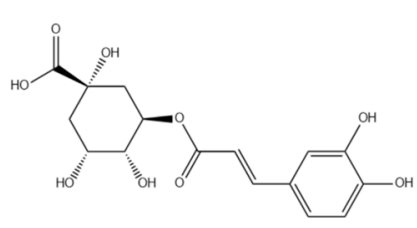

Chlorogenic acid

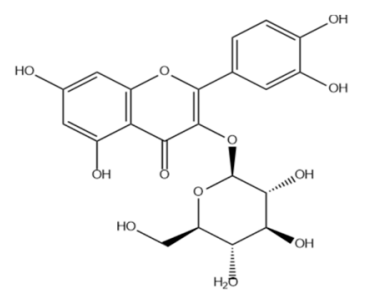

Isoquercetin

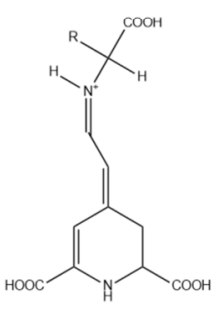

Betaxantins

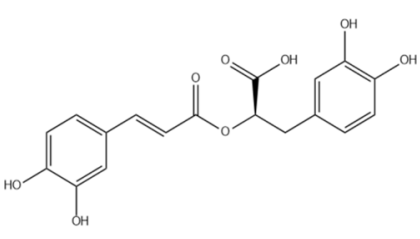

Rosmarinic acid

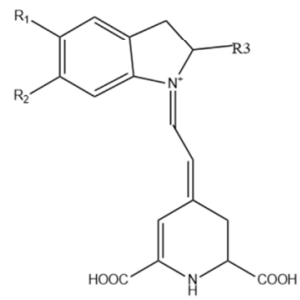

Betacyanins

Figure 3. Chemical structure of the main antioxidant compounds identified in quinoa seeds.

The total flavonoid content in quinoas ranged between 1.77 and $19.29 \mathrm{mg}$ rutin equivalents/g quinoa and also in this case, red and black quinoas showed the highest values $[4,49,85]$. Quercetin, isoquercetin, rutin, hesperidin, neohesperidin, catechin, and epicatechin, among others, are flavonoids with antioxidant activity detected in quinoa samples, being quercetin who shows the strongest antioxidant among the flavonoids [18,83,86]. Stickit et al. [81] detected four flavonoid compounds (aesculin, phorizin, coniferyl aldehyde, and eriodictyol) and one stilbene (pterostilbene) for the first time in quinoa seeds grown in Denmark, but at very low concentration $(0.08-0.53 \mathrm{mg} / \mathrm{kg} \mathrm{dw})$.

Tocopherols belong to a class of phenolic antioxidants that can inhibit lipid autoxidation by scavenging free radicals and by reacting with singlet oxygen. The total tocopherol content reported for quinoa ranged from 37.49 to $59.82 \mu \mathrm{g} / \mathrm{g}$ [8,18,87]. All four tocopherol isoforms $(\alpha, \beta, \gamma$, and $\delta)$ have been detected in quinoa seeds being $\gamma$ tocopherol the predominant isoform in the three varieties (black grains showed the highest concentrations, followed by the red varieties and lastly the white varieties), followed by $\alpha$-tocopherol, $\beta$-tocopherol and $\delta$-tocopherol was the least [18]. Although the most famous antioxidant power has been attributed to the isoform $\alpha-$, recently, it has been reported that $\gamma$-tocopherol is a strong anti-inflammatory agent with equal or even stronger antioxidant properties than the isoform $\alpha$. 
Carotenoids can be not only provitamin A but also strong antioxidants with various healthpromoting properties. The total carotenoid content in quinoa seeds range between 11.87 and $17.61 \mu \mathrm{g} / \mathrm{g}$, showing black quinoa as the highest values [18]. Lutein and zeaxanthin are the two main carotenoids, with lutein being the dominant carotenoid in quinoa seeds. Tang et al. [88] reported that most quinoa seeds also contain $\beta$-carotene.

Betalains are nitrogenous compounds soluble in aqueous media according to their chemical structure, these pigments can be subdivided as red-violet betacyanins or as yellow-orange betaxanthins. Their presence has been reported in colored quinoa grains (yellow and red-violet) $[18,19,26]$. Betalains show high antioxidant and free radical scavenging activities supported by the high antiradical capacity of the pigments' structural unit, betalamic acid [83,89,90]. Escribano et al. [19] evaluated the antioxidant activities of quinoa grains of multiple colors using the FRAP and ABTS assays, reporting that FRAP results indicated a very high antioxidant capacity for the pigmented quinoa samples in comparison with the white and black ones. In addition, they reported that the highest activity was observed for the red-violet varieties, which contain both betacyanins and betaxanthins.

\section{Antioxidant Activity in Chia, Quinoa, and Their Coproducts}

Data variation in the antioxidant capacity of chia and quinoa is to be expected, as many factors such as genetics, agrotechnical processes, and environmental conditions can influence the presence of phenolic compounds [91] as has been mentioned above (point 2). In addition, a comparison of results from different studies can be difficult due to variability in the experimental conditions amongst the methods used for their evaluation [92]. Several antioxidant capacity assays have been applied to evaluate the chemical mechanism involved in the antioxidant action. Depending upon the reactions involved, these assays can roughly be classified into two types: assays based on hydrogen atom transfer (oxygen radical absorbance capacity (ORAC) assay and total radical trapping antioxidant parameter (TRAP), and assays based on electron transfer (Trolox equivalence antioxidant capacity (TEAC) assay or ABTS assay, ferric ion reducing antioxidant power (FRAP) and the DPPH free radical method). In addition, other methods are used to evaluate their chelating activity on specific pro-oxidants, such as the method to measure the ferrous ion chelating activity (FIC) [92]. In other words, it could be said that the FRAP assay measures the ability of quinoa and chia seeds to reduce ferric ion, DPPH, and ABTs assays measure the radical quencher ability and the FIC assay the ability to quench iron.

\subsection{Chia and Its Coproducts}

Considering the molecular structure of the major compounds identified in chia seeds, a high antioxidant activity would be expected: rosmarinic acid and myricetin, the first consists of two aromatic rings and five hydroxyl groups, and the second consists of three aromatic rings with six hydroxyl groups. Thus, these compounds provide high availability of the hydroxyl groups to react with free radicals or reduce other compounds. Pekkarinen et al. [93] showed that compared with other flavonoids (quercetin, kaempferol, catechin, and rutin), myricetin showed the highest antioxidant capacity. Studies prove that myricetin has more phenolic hydroxyl groups, indicating that its antioxidant capacity increases with the number of these hydroxyl groups. So, the high antioxidant activity of chia seeds can be mainly attributed to their high content of phenolic compounds (and also to tocopherols) and it can be developed through to various mechanisms, among which are the prevention of chain initiation, binding of transition metal ion catalysts, decomposition of peroxides, prevention of continued hydrogen abstraction, and radical scavenging protecting against oxidative damage to DNA, proteins, and lipids [94]. Most of the authors reported a high antioxidant activity in chia seeds, comparable to Trolox ${ }^{\circledR}$, suggesting that the phenols in these extracts have an important activity as oxygen singlet quenchers $[3,23,47,55]$. The antioxidant activity of chia seeds has been assessed using different methods, being the most usual ORAC (489-517 $\mu \mathrm{mol}$ TE/g), FRAP (18.5-71.8 mg TE/g), and DPPH (5.4-49.4 mg TE/g) [3,22,60,74] (Table 1). Several authors have reported that the antioxidant activity of chia oil is much lower than chia seeds although it was not proportional to the decrease of the TPC, suggesting that other compounds 
not detected using these analytical conditions could be responsible [60]. The results reported by Xun et al. [77] seem to confirm this, because the DPPH scavenging activity reported for different edible oils was not totally related with the TPC; in the case of chia oil the DPPH value was the lowest, together with avocado oil. In reference to that, Itxaina et al. [45] reported that the high level of polyunsaturated fatty acids (PUFAs) would be the main cause for the low oxidative stability prevailing over the antioxidant effects associated with bioactive components (tocopherols, polyphenols, carotenoids, and phospholipids) present in chia seed oils. Regarding the partially deoiled flour, several authors have found a higher antioxidant activity than in the raw material [3,22]. Vazquez-Obando et al. [95] reported a high antioxidant activity for the chia fiber-rich fraction, (ABTS: $488.8 \mu \mathrm{mol} \mathrm{TE} / \mathrm{g}$ ) similar to that of sorghum bran with high tannin content and higher than those for some wheat grains and sorghum.

\subsection{Quinoa and Its Coproducts}

Many researchers have attributed the antioxidant activity of quinoa seeds only to their hydrophilic phytochemicals, mainly phenolics, but in some cases also betalains $[19,26]$; however, the contribution of lipophilic compounds (tocopherols and carotenoids) must not be underestimated [88]. In reference to the antioxidant properties of quinoa grains (black, white, and colored varieties) attributed to their phenolic compounds, they were assessed using different methods, being the most usual DPPH (0.1-9.7 mg TE/g), ABTS (3.88-7.76 mg TE/g), FRAP (0.7-9 mg TE/g), and FIC (0.59-0.97 $\mu \mathrm{g}$ EDTA/g) assays (Table 1). These results showed a good correlation with phenols and flavonoids content $[4,59,81]$. For all assays, red and black quinoas showed better antioxidant activities than white varieties [4]. In view of these results, it could be indicated greater importance of the antioxidant-antiradical power in comparison with the electron transfer and reducing iron power in quinoa [81]. The antioxidant activities of the lipophilic extracts in quinoa seeds were evaluated by DPPH $(6.26 \mu \mathrm{mol} \mathrm{TE} / \mathrm{g})$, FRAP ( $6.76 \mu \mathrm{mol} \mathrm{AAE} / \mathrm{g})$, and ORAC $(6.69 \mu \mathrm{mol} \mathrm{TE} / \mathrm{g})$ activities and these results also showed good and significant correlations with carotenoids and tocopherols content [88].

Ballester-Sánchez et al. [10] reported higher antioxidant capacity (assessed by DPPH and FRAP analysis) in the fiber-rich fractions (both, obtained by wet and dry-milling process) than in the whole seeds (red quinoa; Table 1). Additionally, in this case the antioxidant activity was much higher in the hydrolysable polyphenol fraction than in the extractable (DPPH: 10.5 fold in whole seeds, between 54 and 40 fold in fiber-rich fractions; FRAP: 6 fold in whole seeds, between 42 and 24 fold in fiber-rich fractions).

\section{Oxidation Stability of Meat Products Containing Chia, Quinoa, or Their Coproducts}

Focusing on reports from the recent 5 years, quinoa and chia-related meat products seem to have aroused great interest in the meat sector not only for the improvement in the nutritional quality of reformulated meat products but also for their beneficial effect on the technological properties and shelf life $[9,24]$. One of the most relevant effects that has been addressed in most of these works has been the effect on lipid oxidation in the meat product, not only on the fresh product but also during its storage, attributing these antioxidant effects to the bioactive compounds with antioxidant properties reported for quinoa and chia seeds [21,96-99]. This oxidation stability on the meat product has been commonly assessed by the reduction in the thiobarbituric acid reactive substances (TBARs values) that has been revealed as the most suitable method for monitoring lipid oxidation in meat and meat products [100]. Table 2 shows chia and quinoa-based meat products and their effect on the lipid oxidation. 
Table 2. Chia and quinoa-based meat products and their effect on the lipid oxidation.

\begin{tabular}{|c|c|c|c|}
\hline Meat Product & Chia/Quinoa & $\begin{array}{l}\text { Effect on Lipid Oxidation } \\
\text { (TBARs Value) }\end{array}$ & References \\
\hline \multirow[t]{9}{*}{ Frankfurter } & chia seeds & $\begin{array}{l}35 \% \text { reduction after } 21 \text { days } \\
\text { refrigerated storage }\end{array}$ & Fernández-López et al. [9] \\
\hline & chia flour & $\begin{array}{l}35 \% \text { reduction after } 21 \text { days } \\
\text { refrigerated storage }\end{array}$ & Fernández-López et al. [9] \\
\hline & chia flour & $\begin{array}{c}300 \% \text { increase } \\
\text { (values }<0.2 \mathrm{mg} \mathrm{MA} / \mathrm{kg} \text { ) }\end{array}$ & Pintado et al. [101] \\
\hline & chia flour & not evaluated & Herrero et al. [102] \\
\hline & deioled chia flour & $\begin{array}{l}35 \% \text { reduction after } 21 \text { days } \\
\text { refrigerated storage }\end{array}$ & Fernández-López et al. [9] \\
\hline & $\begin{array}{c}\text { chia oil } \\
\text { (O/W emulsion) }\end{array}$ & $\begin{array}{c}250 \% \text { increase } \\
\text { (values }<0.2 \text { mg MA/kg) }\end{array}$ & Pintado et al. [101] \\
\hline & $\begin{array}{c}\text { chia oil } \\
\text { (O/W emulsion) }\end{array}$ & not evaluated & Herrero et al. [102] \\
\hline & $\begin{array}{l}\text { chia oil } \\
\text { (emulsion gel) }\end{array}$ & $\begin{array}{c}275 \% \text { increase } \\
\text { (values }<0.2 \mathrm{mg} \mathrm{MA} / \mathrm{kg} \text { ) }\end{array}$ & Pintado et al. [101] \\
\hline & $\begin{array}{l}\text { chia oil } \\
\text { (emulsion gel) }\end{array}$ & not evaluated & Herrero et al. [102] \\
\hline Ham-like product & chia seeds & $30 \%$ reduction & Ding et al. [21] \\
\hline \multirow[t]{11}{*}{ Burgers } & chia seeds & up to $68 \%$ reduction & de Oliveira-Paula et al. [103] \\
\hline & chia seeds & $50 \%$ reduction & Antonini et al. [75] \\
\hline & deffated chia flour & increase TBARs & Souza et al. [96] \\
\hline & chia oil & $\begin{array}{c}25 \% \text { increase in raw burgers, } \\
11 \% \text { after cooking }\end{array}$ & Heck et al. [104] \\
\hline & $\begin{array}{c}\text { chia oil } \\
\text { (microencapsulated) }\end{array}$ & $\begin{array}{c}50 \% \text { increase in raw burgers, } \\
70 \% \text { after cooked }\end{array}$ & Heck et al. [104] \\
\hline & $\begin{array}{l}\text { chia oil } \\
\text { (emulsion gel) }\end{array}$ & $30 \%$ increase & Lucas-González et al. [105] \\
\hline & $\begin{array}{c}\text { chia oil } \\
\text { (hydrogel emulsion) }\end{array}$ & $\begin{array}{l}\text { up to } 350 \% \text { increase } \\
\text { (at } 100 \% \text { substitution level) }\end{array}$ & Heck et al. [106] \\
\hline & $\begin{array}{c}\text { chia oil } \\
\text { (O/W emulsion) }\end{array}$ & not evaluated & De Carvalho et al. [107] \\
\hline & quinoa flour & not evaluated & Shokry [108] \\
\hline & quinoa flour & $\begin{array}{c}20 \% \text { reduction at } 90 \mathrm{~d} \text { frozen } \\
\text { storage }\end{array}$ & Özer and Seçen [109] \\
\hline & quinoa flour & not evaluated & Baioumy et al. [110] \\
\hline Meatballs & quinoa flour & not evaluated & Bagdatli [111] \\
\hline Fresh sausages & chia emulsion gel & not evaluated & Pintado et al. [112] \\
\hline Cooked sausages & $\begin{array}{c}\text { chia oil } \\
\text { (O/W emulsion) }\end{array}$ & $28 \%$ increase & De Carvalho et al. [113] \\
\hline \multirow[t]{2}{*}{ Nuggets } & chia flour & not evaluated & Barros et al. [114] \\
\hline & quinoa flour & not evaluated & Verma et al. [115] \\
\hline \multirow[t]{5}{*}{ Bolognas } & chia flour & not evaluated & Pires et al. [116] \\
\hline & chia emulsion gel & without variation & $\begin{array}{c}\text { de Souza-Paglarini et al. } \\
\text { [117] }\end{array}$ \\
\hline & quinoa grains & $50 \%$ reduction & $\begin{array}{c}\text { Fernández-López et al. } \\
{[98,99]}\end{array}$ \\
\hline & quinoa flour & not evaluated & Vargas-Zambrano et al. [97] \\
\hline & $\begin{array}{c}\text { quinoa } \\
\text { (fiber-rich fraction) }\end{array}$ & $15 \%$ reduction & $\begin{array}{c}\text { Fernández-López et al. } \\
{\left[\begin{array}{l}\text { [98,99] }\end{array}\right.}\end{array}$ \\
\hline Pâté & quinoa flour & $20 \%$ reduction & Pellegrini et al. [118] \\
\hline $\begin{array}{l}\text { Dry-cured } \\
\text { sausages }\end{array}$ & quinoa grains (boiled) & decrease hexanal content & Fernández-Díaz et al. [119] \\
\hline
\end{tabular}




\subsection{Chia Related Meat Products}

Chia has been applied in several meat products (burgers, nuggets, fresh pork sausages, frankfurter-like sausages, and restructured ham-like products, among others) not only as whole chia seeds but also as flour or partially deoiled flour (after oil extraction) $[9,21,75,96,101,103,114,116,119,120]$. This addition was taken off with two main objectives: to partially replace animal fat or to improve their nutritional and techno-functional quality. The addition of 0.5 and $1 \%$ chia seeds in a restructured ham-like product decreased lipid and protein oxidation during 4 weeks of refrigerator storage, attributing this antioxidant effect to the polyphenols in chia [21]. This effect was dependent on the percentage of chia addition: the higher the amount of chia added the lower TBARs values. The addition of chia seeds (up to 8\%) to partially replace animal fat (pork backfat) in chicken hamburgers [103] was effective no only to reduce fat content but also lipid oxidation. Additionally, in this case, the TBARs values of the cooked burgers were dependent on the amount of chia seeds added ( $2 \%, 4 \%$, and $8 \%)$ : higher additions resulted in lower TBARs values. In the same way, Antonini et al. [75] reported that the addition of chia seeds (2.5\% and 5\%) to beef burgers provided a significant reduction in malonaldehyde levels compared to control cooked burgers, though not in a dose-dependent manner. These authors evaluated the polyphenol patterns and antioxidant capacities in these cooked burgers reporting a good correspondence between then, especially for the ORAC and ABTS assays. Frankfurter-type sausages with 3\% chia seeds added showed greater resistance to fat oxidation than control [120]. These authors also reported this antioxidant effect (at the same level as reported for chia seeds) on frankfurter-type sausages when partially deoiled chia flour was added. As has been previously reported, most of the phenolic compounds identified in chia seeds remain in the partially deoiled chia flour after the oil extraction, being responsible for the antioxidant properties. Low-fat frankfurter with chia flour added $(10 \%)$ showed an increase in the oxidative stability during chilling storage, which was attributed to the antioxidant compounds in chia [101]. It is important to highlight that most of these meat products in which the antioxidant effect of chia seeds has been reported are cooked meat products, which means that chia seeds retained its antioxidant effect during cooking [103]. Scapin et al. [121] studied the effect of chia seed extract at concentrations of $0 \%, 1 \%, 1.5 \%$, and $2 \%$ as an antioxidant in fresh pork sausage. They reported TBARs values, after 28 days of storage, of $1.12 \mathrm{mg}$ MDA/kg for the treatment with $2 \%$ chia extract and $1.64 \% \mathrm{mg} \mathrm{MDA} / \mathrm{kg}$ for the control treatment, which is showing the effect of inhibiting lipid oxidation, suggesting their use as natural antioxidant in meat products.

Chia oil has attracted more and more attention for meat researchers to be used as partial replacement of animal fat mainly due to its high content in alpha-linolenic acid (ALA), relatively low levels of saturated fatty acids and does not contain any of the antinutritional compounds or vitamin B6 antagonist factors present in other sources of ALA [122]. The principal problems to the direct incorporation of this oil into meat products are the technological difficulty for their integration in the meat batter, the instability to oxidation (due to the high of unsaturation of fatty acids), and their negative effects on sensorial attributes. To prevent this, several strategies have been developed like microencapsulation with rosemary antioxidants (burgers [104]), conventional oil-in-water emulsions (cooked lamb sausages [107] and frankfurter [102]), double emulsions (meat systems [123]), emulsion gels (burgers [105]; bolognas [117]; and fresh sausages [112]) or hydrogel emulsions (low-fat burgers [106] and lamb sausages [113]). These methodologies allow the chia oil able to be stabilized or immobilized in the protein matrix, reducing the chances of bulk oil physically separating from the structure of the meat product, and so remaining stable during processing and storage. In this sense, Cofrades et al. [123] reported that the presence of chia oil, with the attendant increase in the level of unsaturation of the lipids, promotes lipid oxidation in cooked meat batters, but it also appears to supply some compounds that can help to protect against oxidation (DPPH scavenging activity). However, chia oil is more susceptible to oxidation when it is incorporated in the double emulsion than when added in the liquid form, possibly due to the degree of interaction with meat proteins. 


\subsection{Quinoa Related Meat Products}

Quinoa has been mainly applied in meat products (burgers, meatballs, nuggets, bolognas, pâté, dry-cured sausages, etc.) as the techno-functional ingredient (due to its high protein and carbohydrate content) or as a fat replacer (due to its behavior as a fat-like raw material). In the first case (techno-functional ingredient) it means that quinoa can act like extenders (non-meat compounds with considerable protein content), fillers (plant substances with high carbohydrate content), and binders (substances with high-protein content able to bind both water and fat) $[97-100,108-111,114,115,118,119]$. In the second case (fat replacer) quinoa is used to decrease or totally replace the animal fat content in meat products. However, although these have been the main purpose, several authors have reported that their addition helped to control the development of lipid oxidation in the meat product. Özer and Seçen [109] added quinoa flour (up to 10\%; in substitution of breadcrumbs) to beef burgers with the corresponding improvement in burger quality and cooking properties. Additionally, they also found that quinoa flour inhibited lipid oxidation during frozen storage. The antioxidant effect of quinoa flour was identified in raw beef burgers at all usage rates $(3 \%, 5 \%, 7 \%$, and $10 \%)$ during $-18{ }^{\circ} \mathrm{C}$ storage for 90 days. These antioxidant properties of quinoa flour were also observed when these burgers were cooked, attributing this antioxidant effect to the phenolic and flavonoid content in quinoa as a source of free radical scavenging agents [124]. Fernández-López et al. [98,99] investigated the application of black quinoa seeds (as whole seeds or as their fiber-rich fraction obtained as a coproduct from the quinoa wet-milling process) in bologna-type sausages (up to 3\%; in substitution of potato starch). These authors reported that it was a feasible strategy for reformulating cooked sausages and maybe a good choice not only for enhancing the nutritional composition of the bolognas but also for their effect on the technological properties, such as to enhance emulsion stability and to decrease lipid oxidation. In this work, bolognas with quinoa added showed lower TBARs values than control, showing bolognas with quinoa added as whole seeds the lowest TBARs value. It must be taken into account that the fiber-rich fraction is obtained as a coproduct from the wet-milling process of quinoa seeds (whose main product is starch), which implies the use of large quantities of water to allow this fractionation processes [125]. In addition, Lin et al. [84] reported that most of the compounds with antioxidant properties in quinoa seeds are located in the inner of the grain, and only a reduced amount has been identified in bran. This antioxidant effect of black quinoa in bolognas was also confirmed during their refrigerated storage, showing sausages with quinoa products added lower TBAR values than the control for all the days studied, and also, in this case, sausages with quinoa seeds showed the lowest TBAR values throughout the entire storage period (21 days) [99].

Pellegrini et al. [118] used white, red, and black quinoa pastes as the "fat-mimetic" ingredient to reduce the fat content (up to 10\%) in the pâté. This reformulation not only increased the healthiness of the product (lower fat and higher fiber content) but also showed beneficial effects on their stability (higher emulsion stability and lower lipid oxidation) without negatively affecting microbial and sensorial quality. All pâté samples with $10 \%$ quinoa added (white, black, or red quinoa) showed lower TBAR values than the control. However, when they were added at $5 \%$, only samples with black quinoa achieved significantly lower TBAR values than the control. In this case, the higher content in antioxidant compounds reported for black quinoa (in relation to white and red varieties) could explain this behavior. Several authors have reported differences in the content of antioxidant compounds (polyphenols, tocopherols, betalains, carotenoids, etc.) and their antioxidant activity depending on the quinoa color (white, red, black, violet, yellow, etc.) [4,19], which has been previously highlighted and discussed (points 2.2 and 3.2). Fernández-Diez et al. [119] is the only reference found about the use of quinoa (boiled grains) in dry-cured sausages. In this case, the authors estimated the effect of quinoa addition on the lipid oxidation by means of the determination of the volatile compounds. They reported that volatiles formed via lipid oxidation such as straight medium-chain aldehydes and ketones, which represent the majority of the straight medium-chain alkyl compound group, seemed to decrease with fat reduction and quinoa addition. 


\section{Conclusions}

The meat industry is demanding antioxidants from natural sources to replace synthetic ones because of the negative concerns regarding some of the synthetic antioxidants. Chia and quinoa seeds and their coproducts, as the same as other plant materials, provide good alternatives due to their content in bioactive compounds (mainly phenolic compounds), which various kinds of biological activities, antioxidant properties included. The main bioactive compounds identified in quinoa products include phenolic acids (mainly rosmarinic and chlorogenic acids), flavonoids (mainly quercetin and isoquercetin), and nitrogen-containing compounds (mainly betalains: betacyanins, and betaxanthins). These last compounds are water-soluble pigments of hydrophilic nature with promising bioactive potential, identified in colored quinoa grains (violet, red, and yellow), becoming one of the scarce edible sources of betalains. On the other hand, chia products have been reported as a good source of phenolic acids (mainly rosmarinic, ferulic, and caffeic acids) and flavonoids (mainly rutin, myricetin, and quercetin). Isoflavones (mainly daidzin, genistin, and genistein) and tocopherols ( $\gamma$-tocopherol as the predominant one) have also been identified in chia products. All this richness in antioxidant compounds has allowed their application in meat product formulation not only for their improvement in nutritional and technological quality but also for their antioxidant properties mainly shown in the lipid oxidation control. Among other effects, the factors associated with the way in which these ingredients are incorporated to the meat matrix (flour, oil, emulsions, emulsion gels, etc.), the complexity of this matrix (emulsified meat product, cooked meat product, dry-cured meat product, etc.) or the nature of other ingredients in the formulation (sodium chloride, nitrites, phosphates, etc.) could be a limit to the possibilities of establishing clear relationships among parameters of lipid oxidation and antioxidant capacity of the matrix. In any way, chia and quinoa products open a wide range of opportunities for the meat industry to reformulate processed meat products in view of healthier and cleaner meat products production. In addition to optimizing the formulation to avoid technological problems and to ensure a positive sensorial evaluation of the final meat product, it could be interesting to assess the effect of digestion process on the stability and bioaccessibility of these bioactive compounds and their antioxidant properties using in vitro digestion studies.

Author Contributions: Conceptualization, J.F.-L. and J.A.P.-A.; methodology, C.N.-R.d.V. and M.E.S.-B.; investigation, M.V.-M., J.F.-L. and J.A.P.-A.; resources, R.L.-G., A.R.-V. and C.B.-M.; writing-original draft preparation, M.V.-M. and J.F.-L.; writing-review and editing, J.F.-L. and J.A.P.-A.; funding acquisition, J.A.P.-A. All authors have read and agreed to the published version of the manuscript.

Funding: This research was funded by FEDER/Ministry of Science and Innovation (MCI-Spain), State Research Agency (AEI) project number "AGL2016-75687-C2-2-R" (MCI/AEI/FEDER, UE).

Acknowledgments: IPOA researchers are members of the HealthyMeat network, funded by CYTED (ref. 119RT0568). R.L.-G. enjoy a grant from UMH for doctoral formation.

Conflicts of Interest: The authors declare no conflict of interest.

\section{References}

1. Sharma, V.; Chandra, S.; Dwivedi, P.; Parturkar, M. Quinoa (Chenopodium quinoa Willd.): A nutritional healthy grain. Intern. J. Adv. Res. 2015, 3, 725-736.

2. Gordillo-Bastida, E.; Díaz-Rizzolo, D.A.; Roura, E.; Massanés, T.; Gomis, R. Quinoa (Chenopodium quinoa Willd), from nutritional value to potential health benefits: An integrative review. J. Nutr. Food Sci. 2016, 6, 1000497.

3. Pellegrini, M.; Lucas-González, R.; Sayas-Barberá, E.; Fernández-López, J.; Pérez-Alvarez, J.A.; Viuda-Martos, M. Bioaccessibility of phenolic compounds and antioxidant capacity of chia seeds. Plant Foods Hum. Nutr. 2018, 73, 47-53. [CrossRef] [PubMed]

4. Pellegrini, M.; Lucas-González, R.; Ricci, A.; Fontecha, J.; Fernández-López, J.; Pérez-Alvarez, J.A.; Viuda-Martos, M. Chemical, fatty acid, polyphenolic profile, techno-functional and antioxidant properties of flours obtained from quinoa (Chenopodium quinoa Willd) seeds. Ind. Crops Prod. 2018, 111, 38-46. [CrossRef] 
5. Wang, S.; Zhu, F. Formulation and quality attributes of quinoa food products. Food Bioprocess Technol. 2016, 9 , 49-68. [CrossRef]

6. Zettel, V.; Hitzmann, B. Applications of chia (Salvia hispanica L.) in food products. Trends Food Sci. Technol. 2018, 80, 43-50. [CrossRef]

7. Ceyhun-Sezgin, A.; Sanlier, N. A new generation plant for the conventional cuisine: Quinoa (Chenopodium quinoa Willd). Trends Food Sci. Technol. 2019, 86, 51-58. [CrossRef]

8. Pereira, E.; Encina-Zelada, C.; Barros, L.; Gonzales-Barron, U.; Cadavez, V.; Ferreira, I.C.F.R. Chemical and nutritional characterization of Chenopodium quinoa Willd (quinoa) grains: A good alternative to nutritious food. Food Chem. 2019, 280, 110-114. [CrossRef]

9. Fernández-López, J.; Viuda-Martos, M.; Pérez-Alvarez, J.A. Quinoa and chia products as ingredients for healthier processed meat products: Technological strategies for their application and effects on the final product. Curr. Opin. Food Sci. 2020, 40, 26-32. [CrossRef]

10. Ballester-Sánchez, J.; Fernández-Espinar, M.T.; Haros, C.M. Isolation of red quinoa fibre by wet and dry milling and application as a potential functional bakery ingredient. Food Hydrocoll. 2020, 101, 105513. [CrossRef]

11. De Falco, B.; Amato, M.; Lanzotti, V. Chia seeds products: An overview. Phytochem. Rev. 2017, 16, 745-760. [CrossRef]

12. Ballester-Sánchez, J.; Vicente-Gil, J.; Haros, C.M.; Fernández-Espinar, M.T. Effect of incorporating white, red or black quinoa flours on free and bound polyphenol content, antioxidant activity and colour of bread. Plant Foods Hum. Nutr. 2019, 74, 185-191.

13. Aranibar, C.; Pigni, N.B.; Martinez, M.; Aguirre, A.; Ribotta, P.; Wunderlin, D.; Borneo, R. Utilization of a partially-deoiled chia flour to improve the nutritional and antioxidant properties of wheat pasta. LWT Food Sci. Technol. 2018, 89, 381-387. [CrossRef]

14. Atwa, E.H.; Ghada, M.E.A. Effect of chia and quinoa seeds extract as natural antioxidant on the oxidative stability of fermented cream analogue. J. Food Dairy Sci. 2020, 11, 51-57. [CrossRef]

15. Navruz-Varli, S.; Sanlier, N. Nutritional and health benefits of quinoa (Chenopodium quinoa Willd). J. Cereal Sci. 2019, 69, 371-376. [CrossRef]

16. Nowak, V.; Du, J.; Charrondière, U.R. Assesment of the nutritional composition of quinoa (Chenopodium quinoa Willd). Food Chem. 2016, 193, 47-54. [CrossRef]

17. Vilacundo, R.; Hernández-Ledesma, B. Nutritional and biological value of quinoa (Chenopodium quinoa Willd). Curr. Opin. Food Sci. 2017, 14, 1-6. [CrossRef]

18. Tang, Y.; Li, X.; Zhang, B.; Chen, P.X.; Liu, R.; Tsao, R. Characterization of phenolics, betanins and antioxidant activities in seeds of three Chenopodium quinoa Willd. genotypes. Food Chem. 2015, 166, 380-388. [CrossRef]

19. Escribano, J.; Cabanes, J.; Jiménez-Atiénzar, M.; Ibañez-Tremolada, M.; Gómez-Pando, L.R.; García-Carmona, F.; Gandía-Herrero, F. Characterization of betalains, saponins and antioxidant power in differently colored quinoa (Chenopodium quinoa) varieties. Food Chem. 2017, 234, 285-294. [CrossRef]

20. Muñoz, I.A.; Cobos, A.; Díaz, O.; Aguilera, J.M. Chia seed (Salvia hispanica): An ancient grain and a new functional food. Food Rev. Intern. 2013, 29, 394-408. [CrossRef]

21. Ding, Y.; Lin, H.W.; Lin, Y.L.; Yang, D.J.; Yu, Y.S.; Chen, W., Jr.; Wang, S.Y.; Chen, Y.C. Nutritional composition in the chia seed and its processing properties on restructured ham-like products. J. Food Drug Anal. 2018, 26, 124-134. [CrossRef] [PubMed]

22. Fernández-López, J.; Lucas-González, R.; Viuda-Martos, M.; Sayas-Barberá, E.; Pérez-Alvarez, J.A. Chia oil extraction coproduct as a potential new ingredient for the food industry: Chemical, physicochemical, techno-functional and antioxidant properties. Plant Foods Hum. Nutr. 2018, 73, 130-136. [CrossRef] [PubMed]

23. Reyes-Caudillo, E.; Tecante, A.; Valdivia-López, M.A. Dietary fibre content and antioxidant activity of phenolic compounds present in Mexican chia (Salvia hispanica L.) seeds. Food Chem. 2008, 107, 656-663. [CrossRef]

24. Pintado, T.; Ruiz-Capillas, C.; Herrero, A.M. New lipid materials based on chia emulsion gels. Application in meat products. Biomed. J. Sci. Tech. Res. 2019, 18, 13215-13218. [CrossRef]

25. Martínez-Cruz, O.; Paredes-López, O. Phytochemical profile and nutraceutical potential of chia sedes (Salvia hispanica L) by ultra high performance liquid chromatography. J. Chromatogr. A 2014, 1346, 43-48. [CrossRef] [PubMed] 
26. Abderrahim, F.; Huanatico, E.; Segura, R.; Arribas, S.; Gonzalez, M.C.; Condezo-Hoyos, L. Physical features, phenolic compounds, betalains and total antioxidant capacity of coloured quinoa seeds (Chenopodium quinoa Willd.) from Peruvian Altiplano. Food Chem. 2015, 183, 83-90. [CrossRef] [PubMed]

27. Noratto, G.D.; Murphy, K.; Chew, B.P. Quinoa intake reduces plasma and liver cholesterol, lessens obesity associated inflammation, and helps to prevent hepatic steatosis in obese db/db mouse. Food Chem. 2019, 287, 107-114. [CrossRef] [PubMed]

28. Repo-Carrasco-Valencia, R. Dietary fibre and bioactive compounds of kernels. In Pseudocereals: Chemistry and technology; Haros, C.M., Schoenlechner, R., Eds.; John Wiley \& Sons, Ltd.: Oxfork, UK, 2017; pp. 71-93.

29. Singh, A.; Kukreti, R.; Saso, L.; Kukreti, S. Oxidative stress: A key modulator in neurodegenerative diseases. Molecules 2019, 24, 1583. [CrossRef] [PubMed]

30. Chaijan, M.; Panpipat, W. Mechanism of oxidation in foods of animal origin. Chapter 1. In Natural Antioxidants: Applications in Foods of Animal Origin; Banerjee, R., Verma, A.K., Siddiqui, M.W., Eds.; CRC Press: Oakville, ON, Canada, 2017; pp. 1-50.

31. Maqsood, S.; Benjakul, S. Comparative studies on molecular changes and pro-oxidative activity of haemoglobin from different fish species as influenced by $\mathrm{pH}$. Food Chem. 2011, 124, 875-883. [CrossRef]

32. Naveena, B.M.; Sen, A.R.; Vaithiyanathan, S.; Babji, Y.; Kondaiah, N. Comparative efficacy of pomegranate juice, pomegranate rind powder extract and BHT as antioxidants in cooked chicken patties. Meat Sci. 2008, 80, 304-308. [CrossRef]

33. Karre, L.; Lopez, K.; Getty, K.J.K. Natural antioxidants in meat and poultry products. Meat Sci. 2013, 94, 220-227. [CrossRef] [PubMed]

34. Hang, D.; Mcmillin, K.W.; Godber, J.S. Hemoglobin, myoglobin and total pigments in beef and chicken muscles: Chromatographic determination. J. Food Sci. 1994, 59, 1279-1282.

35. Richards, M.P.; Dettmann, M.A. Comparative analysis of different hemoglobins: Autoxidation, reaction with peroxide and lipid oxidation. J. Agric. Food Chem. 2003, 51, 3886-3891. [CrossRef] [PubMed]

36. Papuc, C.; Goran, G.V.; Predescu, C.N.; Nicorescu, V. Mechanisms of oxidative processes in meat and toxicity induced by postprandial degradation products: Review. Compr. Rev. Food Sci. Food Saf. 2017, 16, $96-123$. [CrossRef]

37. Love, J.D.; Pearson, A.M. Lipid oxidation in meat and meat products. A review. J. Am. Oil Chem. Soc. 1971, 48, 547-549. [CrossRef]

38. Cheng, J.; Ockerman, H.W. Effect of phosphate with tumbling on lipid oxidation of precooked roast beef. Meat Sci. 2003, 65, 1353-1359. [CrossRef]

39. Kumar, Y.; Yadav, D.N.; Ahmad, T.; Narsaiah, K. Recent Trends in the use of natural antioxidants for meat and meat products. Compr. Rev. Food Sci. Food Saf. 2015, 14, 796-812. [CrossRef]

40. Branen, A.L. Toxicology and biochemistry of butylated hydroxy anisole and butylated hidroxy toluene. J. Am. Oil Chem Soc. 1975, 52, 59-63. [CrossRef]

41. Lindenschmidt, R.C.; Tryka, A.F.; Goad, M.E.; Witschi, H.P. The effects of dietary butylated hydroxytoluene on liver and colon tumor development in mice. Toxicology 1986, 38, 151-160. [CrossRef]

42. Cieslik, E.; Geda, A.; Adamus, W. Contents of polyphenols in fruit and vegetables. Food Chem. 2006, 94, 135-142. [CrossRef]

43. Viuda-Martos, M.; Ruiz-Navajas, Y.; Fernández-López, J.; Pérez-Alvarez, J.A. Spices as functional foods. Crit. Rev. Food Sci. Nutr. 2010, 51, 13-28. [CrossRef] [PubMed]

44. Álvarez-Chávez, L.M.; Valdivia-López, M.A.; Aburto-Juárez, M.L.; Tecante, A. Chemical characterization of the lipid fraction of Mexican chia seed (Salvia hispanica L.). Intern. J. Food Prop. 2008, 11, 687-697. [CrossRef]

45. Ixtaina, V.Y.; Martínez, M.L.; Spotorno, V.; Mateo, C.M.; Maestri, D.M.; Diehl, B.W.K. Characterization of chia seed oils obtained by pressing and solvent extraction. J. Food Compos. Anal. 2011, 24, 166-174. [CrossRef]

46. Capitani, M.I.; Spotorno, V.; Nolasco, S.M.; Tomás, M.C. Physicochemical and functional characterization of by-products from chia (Salvia hispanica L.) seeds of Argentina. LWT-Food Sci. Technol. 2012, 45, 94-102. [CrossRef]

47. Marineli, R.S.; Moraes, E.A.; Lenquiste, S.A.; Godoy, A.T.; Eberlin, M.N.; Marostica Junior, M.R. Chemical characterization and antioxidant potential of Chilean chia seeds and oil (Salvia hispanica L.). LWT Food Sci. Technol. 2014, 59, 1304-1310. [CrossRef]

48. Dini, I.; Tenore, G.C.; Dini, A. Antioxidant compounds content and antioxidant activity before and after cooking in sweet and bitter Chenopodium quinoa seeds. LWT-Food Sci. Technol. 2010, 43, 447-451. [CrossRef] 
49. Liu, M.; Zhu, K.; Yao, Y.; Chen, Y.; Guo, H.; Ren, G.; Yang, X.; Li, J. Antioxidan, anti-inflamatory, and antitumor activities of phenolic compounds from white, red, and black Chenopodium quinoa seed. Cereal Chem. 2020, 97, 703-713. [CrossRef]

50. Nijveldt, R.J.; van Nood, E.; van Hoorn, E.C.; Boelens, P.G.; van Norren, K.; van Leeuwen, P.A. Flavonoids: A review of probable mechanisms of action and potential applications. Am. J. Clin. Nutr. 2001, 74, 418-425. [CrossRef]

51. Ayerza, R.; Coates, W. Influence of environment on growing period and yield, protein, oil, and $\alpha$-linolenic content of three chia (Salvia hispanica L.) selections. Ind. Crops Prod. 2009, 30, 321-324. [CrossRef]

52. Mezadri, T.; Villaño, D.; Fernández-Pachón, M.S.; García-Parrilla, M.C.; Troncoso, A.M. Antioxidant compounds and antioxidant activity in acerola (Malpighia emarginata DC.) fruits and derivatives. J. Food Compos. Anal. 2008, 21, 282-290. [CrossRef]

53. Vasco, C.; Ruales, J.; Kamal-Eldin, A. Total phenolic compounds and antioxidant capacities of major fruits from Ecuador. Food Chem. 2008, 111, 816-823. [CrossRef]

54. Cho, K.M.; Ha, T.J.; Lee, Y.B.; Seo, W.D.; Kim, J.Y.; Ryu, H.W.; Jeong, S.H.; Kang, Y.M.; Lee, J.H. Soluble phenolics and antioxidant properties of soybean (Glycine max L.) cultivars with varying seed coat colours. J. Funct. Foods 2013, 5, 1065-1076. [CrossRef]

55. Alcântara, M.A.; Polari, I.L.B.; Meireles, B.R.L.A.; Alcântara de Lima, A.E.; da Silva, J.C., Jr.; Vieira, E.A.; dos Santos, N.A.; Cordeiro, A.M.T.M. Effect of the solvent composition on the profile of phenolic compounds extracted from chia seeds. Food Chem. 2019, 275, 489-496. [CrossRef] [PubMed]

56. Da Silva, B.P.; Anunciaçao, P.C.; Matyelka, J.C.S.; Lucia, C.M.D.; Martino, H.S.D.; Pinheiro-Sant'Ana, H.M. Chemical composition of Brazilian chia seeds grown in different places. Food Chem. 2017, 221, 1709-1716. [CrossRef] [PubMed]

57. Serpen, A.; Capuano, E.; Fogliano, V.; Gökmen, V. A new procedure to measure the antioxidant activity of insoluble food components. J. Agric. Food Chem. 2007, 55, 7676-7681. [CrossRef] [PubMed]

58. Serpen, A.; Gökmen, V.; Fogliano, V. Total antioxidant capacities of raw and cooked meats. Meat Sci. 2012, 90, 60-65. [CrossRef] [PubMed]

59. Sargy, S.C.; Silva, B.C.; Santos, H.M.C.; Montanher, P.F.; Boeing, J.S.; Santos, O.O., Jr.; Souza, N.E.; Visentainer, J.V. Antioxidant capacity and chemical composition in seeds rich in omega-3: Chia, flax and perilla. Food Sci. Technol. 2013, 33, 541-548. [CrossRef]

60. Oliveira-Alves, S.C.; Vendramini-Costa, D.B.; Cazarin, C.B.B.; Maróstica Júnior, M.B.; Ferrerira, J.P.B.; Silva, A.B.; Prado, M.A.; Bronze, M.R. Characterization of phenolic compounds in chia (Salvia hispanica L.) seeds, fiber flour and oil. Food Chem. 2017, 232, 295-305. [CrossRef]

61. Brend, Y.; Galili, I.; Badani, H.; Hovav, R.; Galili, S. Total phenolic content and antioxidant activity or red and yellow quinoa (Chenopodium quinoa Willd.) seeds as affected by baking and cooking conditions. Food Nutr. Sci. 2012, 3, 1150-1155. [CrossRef]

62. Pasko, P.; Barton, H.; Zagrodzki, P.; Gorinstein, S.; Folta, M.; Zachwieja, Z. Anthocyanins, total polyphenols and antioxidant activity capacity of coloured quinoa seeds (Chenopodium quinoa Willd.) from Peruvian Altiplano. Food Chem. 2009, 115, 994-998.

63. Valencia, Z.; Cámara, F.; Ccapa, K.; Catacora, P.; Quispe, F. Bioactive compounds and antioxidant activity from peruvian quinoa seeds (Chenopodium quinoa W.). Rev. Soc. Quim. Perú 2017, 83, 16-29.

64. Sobota, A.; Swieca, M.; Gesinski, K.; Wirkijowska, A.; Bochnak, J. Yellow-coated quinoa (Chenopodium quinoa Willd) - physicochemical, nutritional and antioxidant properties. J. Sci. Food Agric. 2020, 100, $2035-2042$. [CrossRef] [PubMed]

65. Repo-Carrasco-Valencia, R.; Hellström, J.K.; Pihlava, J.M.; Matilla, P.H. Flavonoids and other phenolic compounds in Andean indigenous grains: Quinoa (Chenopodium quinoa), kañiwa (Chenopodium pallidicaule) and kiwicha (Amaranthus caudatus). Food Chem. 2010, 120, 128-133. [CrossRef]

66. Repo-Carrasco-Valencia, R.; Zelada, C.R.E. Determinación de la capacidad antioxidante y compuestos fenólicos de cereales andinos: Quinoa (Chenopodium quinoa), kañiwa (Chenopodium pallidicause) y kiwicha (Amaranths caudatus). Rev. Soc. Quim. Perú 2008, 74, 85-99.

67. Díaz-Valencia, Y.K.; Alca, J.A.; Calori-Domingues, M.A.; Zanabria-Galvez, S.J.; Da Cruz, S.H. Nutritional composition, total phenolic compounds and antioxidant activity of quinoa (Chenopodium quinoa Willd.) of different colours. Nova Biotechnol. Chi. 2018, 17, 74-85. [CrossRef] 
68. Farajzadeht, Z.; Shakerian, A.; Rahimi, E.; Bagheri, M. Chemical, antioxidant, total phenolic and flavonoid components and antimicrobial effects of different species of quinoa seeds. Egypt. J. Vet. Sci. 2020, 51, 43-54. [CrossRef]

69. Vázquez-Luna, A.; Fuentes, F.; Rivadeneyra, E.; Hernández, C.; Díaz-Sobac, R. Nutrimental content and functional properties of quinoa flour from Chile and Mexico. Int. J. Agric. Nat. Resour. 2019, 46, 144-153. [CrossRef]

70. Sohaimy, S.A.; Mohamed, S.E.; Shehata, M.G.; Mehany, T.; Zaitoun, M.A. Compositional analysis and functional characteristics of quinoa flour. Ann. Res. Rev. Biol. 2018, 22, 1-11. [CrossRef]

71. Aguilar, J.; Miano, A.C.; Obregón, J.; Soriano-Colchado, J.; Barraza-Jáuregui, G. Malting process as an alternative to obtain high nutritional quality quinoa flour. J Cereal Sci. 2019, 90, 102858. [CrossRef]

72. Caruso, M.C.; Favati, F.; Di Cairano, M.; Galgano, F.; Labella, R.; Scarpa, R.; Condelli, N. Shelf-life evaluation and nutraceutical properties of chia seeds from a recent long-day flowering genotype cultivated in Mediterranean área. LWT-Food Sci. Technol. 2018, 87, 400-405. [CrossRef]

73. Porras-Loaiza, P.; Jiménez-Munguía, M.T.; Sosa-Morales, M.E.; Palou, E.; López-Malo, A. Physical properties, chemical characterization and fatty acid composition of Mexican chia (Salvia hispánica L.) seeds. Int. J. Food Sci. Technol. 2014, 49, 571-577. [CrossRef]

74. Tunçil, Y.E.; Çelik, O.F. Total phenolic contents, antioxidant and antibacterial activities of chia seeds (Salvia hispanica L.) having different coat color. Akademik Ziraat Dergisi 2019, 8, 113-120. [CrossRef]

75. Antonini, E.; Torri, L.; Piochi, M.; Cabrino, G.; Meli, M.A.; De Bellis, R. Nutritional, antioxidant and sensory properties of functional beef burgers formulated with chia seeds and goji puree, before and after in vitro digestion. Meat Sci. 2020, 161, 108021. [CrossRef]

76. Dick, M.; Pagno, C.H.; Haas-Costa, T.M.; Gomaa, A.; Subirade, M.; de Oliveira Rios, A.; Hickmann-Flîres, S. Edible films base on chia flour: Development and characterization. Polym. Sci. 2016, 133, 42455.

77. Xuan, T.D.; Ganggiang, G.; Minh, T.N.; Quy, T.N.; Dang, T. An overview of chemical profiles, antioxidant and antimicrobial activities of commercial vegetable edible oils marketed in Japan. Foods 2018, 7, 21. [CrossRef]

78. Guiotto, E.N.; Ixtaina, V.Y.; Nolasco, S.M.; Tomás, M.C.M. Effect of storage conditions and antioxidants on the oxidative stability of sunflower-chia oil blends. J. Am. Oil Chem. Soc. 2014, 91, 767-776. [CrossRef]

79. Tuberoso, C.; Kowalczyk, A.; Sarritzu, E.; Cabras, P. Determination of antioxidant compounds and antioxidant activity in commercial oilseeds for food use. Food Chem. 2007, 103, 1494-1501. [CrossRef]

80. Dąbrowski, G.; Konopka, I.; Czaplicki, S. Supercritical $\mathrm{CO}_{2}$ extraction in chia oils production: Impact of process duration and co-solvent addition. Food Sci. Biotechnol. 2018, 27, 677-686. [CrossRef]

81. Stikic, R.I.; Milincic, D.D.; Kostic, A.Z.; Jovanovic, Z.B.; Gasic, U.M.; Tesic, Z.L.; Djordjevic, N.Z.; Savic, S.K.; Czekus, B.G.; Pesic, M.B. Polyphenolic profiles, antioxidant, and in vitro anticancer activities of the seeds of Puno and Titicaca quinoa cultivars. Cereal Chem. 2020, 97, 626-633. [CrossRef]

82. Gao, K.; Zhang, W.T.; Tang, Y.; Li, X.H.; Rong, T. Phenolic composition and antioxidant activities in Canada's quinoa. Food Ferment. Ind. 2016, 42, 107-113.

83. Lin, M.; Han, P.; Li, Y.; Wang, W.; Lai, D.; Zhou, L. Quinoa secondary metabolites and their biological activities or functions. Molecules 2019, 24, 2512. [CrossRef]

84. Tang, Y.; Tsao, R. Phytochemicals in quinoa and amaranth grains and their antioxidant, anti-inflammatory, and potential health beneficial effects: A review. Mol. Nutr. Food Res. 2017, 61, 1600767. [CrossRef] [PubMed]

85. Chacaliaza-Rodríguez, L.; Espinoza-Begazo, G.; Ramos-Escudero, F.; Servan, K. Proximate chemical composition and content of biologically active components in leaves of two quinoa cultivars (Salcedo and Altiplano) produced in Peru. Res. J. Med. Plants. 2016, 10, 450-456.

86. Carciochi, R.A.; Manrique, G.D.; Dimitrov, K. Changes in phenolic composition and antioxidant activity during germination of quinoa seeds (Chenopodium quinoa Willd.). Intern. Food Res. J. 2014, 21, 767-773.

87. Ng, S.C.; Anderson, A.; Coker, J.; Ondrus, M. Characterization of lipid oxidantion proudcts in quinoa (Chenopodium quinoa). Food Chem. 2007, 101, 185-192. [CrossRef]

88. Tang, Y.; Li, X.; Chen, P.X.; Zhang, B.; Liu, R.; Hernández, M.; Draves, J.; Marcone, M.F.; Tsao, R. Assessing the fatty acid, carotenoid, and tocopherol compositions of amaranth and quinoa seeds grown in Ontario and their overall contribution to nutritional quality. J. Agric. Food Chem. 2016, 64, 1103-1110. [CrossRef]

89. Gandía-Herrerro, F.; Escribano, J.; García-Carmona, F. The role of phenokic hydroxy groups in the free radical scavenging activity of betalains. J. Nat. Prod. 2009, 72, 1142-1146. [CrossRef] 
90. Gandía-Herrerro, F.; Escribano, J.; García-Carmona, F. Biological activities of plant pigments betalains. Crit. Rev. Food Sci. Nutr. 2016, 56, 937-945. [CrossRef]

91. Nsimba, R.Y.; Kikizaki, H.; Konishi, Y. Antioxidant activity of various extracts and fractions of Chenopodium quinoa and Amaranthus spp. seeds. Food Chem. 2008, 106, 760-766. [CrossRef]

92. 7Huang, D.; Ou, B.; Prior, R.L. The chemistry behind antioxidant capacity assays. J. Agric. Food Chem. 2005, 53, 1841-1856.

93. Pekkarinen, S.S.; Heinonen, I.M.; Hopia, A.I. Flavonoid quercetin, myrcetin, kaemferol and (+)-catechin as antioxidants in methyl linoleate. J. Sci. Food Agric. 1999, 79, 499-506. [CrossRef]

94. Halliwell, B. Free radicals and antioxidants: A personal view. Nutr. Rev. 1994, 52, 253-265. [CrossRef] [PubMed]

95. Vázquez-Ovando, A.; Rosado-Rubio, G.; Chel-Guerrero, L.; Betancur-Ancona, D. Physicochemical properties of a fibrous fraction from chia (Salvia hispánica L.). LWT-Food Sci. Technol. 2009, 42, 168-173.

96. Souza, A.H.P.; Gohara, A.K.; Rotta, E.M.; Chaves, M.A.; Silva, C.M.; Dias, L.F.; Gomes, S.T.M.; Souza, N.E.; Matsushita, M. Effect of the addition of chia's by-product on the composition of fatty acids in hamburgers through chemometric methods. J. Sci. Food Agric. 2015, 95, 928-935. [CrossRef] [PubMed]

97. Vargas-Zambrano, P.; Riera-González, G.; Cruz-Viera, L. Quinoa as gelling agent in a mortadela formulation. Int. Food Res. J. 2019, 26, 1069-1077.

98. Fernández-López, J.; Lucas-González, R.; Viuda-Martos, M.; Sayas-Barberá, M.E.; Ballester-Sánchez, J.; Haros, C.M.; Martínez-Mayoral, A.; Pérez-Alvarez, J.A. Chemical and technological properties of bologna-type sausages with added black quinoa wet-milling coproducts as binder replacer. Food Chem. 2020, 310, 125936. [CrossRef] [PubMed]

99. Fernández-López, J.; Lucas-González, R.; Roldán-Verdú, A.; Viuda-Martos, M.; Sayas-Barberá, E.; Ballester-Sánchez, J.; Haros, C.M.; Pérez-Alvarez, J.A. Effects of black quinoa wet-milling coproducts on the quality properties of bologna-type sausages during cold storage. Foods 2020, 9, 274. [CrossRef]

100. Fernández-López, J.; Pérez-Alvarez, J.A.; Fernández-López, J.A. Thiobarbituric acid test for monitoring lipid oxidation in meat. Food Chem. 1997, 59, 345-353. [CrossRef]

101. Pintado, T.; Herrero, A.M.; Jiménez-Colmenero, F.; Ruiz-Capillas, C. Strategies for incorporation of chia (Salvia hispánica L.) in frankfurters as a health-promoting ingredient. Meat Sci. 2016, 114, 75-84. [CrossRef]

102. Herrero, A.M.; Ruiz-Capillas, C.; Pintado, T.; Carmona, P.; Jiménez-Colmenero, F. Infrared spectroscopy used to determine effects of chia and olive oil incorporation strategies on lipid structure of reduced-fat frankfurters. Food Chem. 2017, 221, 1333-1339. [CrossRef]

103. de Oliveira-Paula, M.M.; Gonçalves-Silva, J.R.; de Oliveira, K.L.; Massingue, A.; Mendes-Ramos, E.; Benevenuto, A.A., Jr.; Louzalda-Silva, M.H.; Olmi-Silva, V.R. Technological and sensory characteristics of hamburgers added with chia seed as fat replacer. Ciência Rural. 2019, 49, 320190090.

104. Heck, R.T.; Lucas, B.N.; Dos Santos, D.J.P.; Pinton, M.B.; Fagundes, M.B.; Etchepare, M.A.; Cichoski, A.J.; de Menezes, C.R.; Barin, J.S.; Wagner, R.; et al. Oxidative stability of burgers containing chia oil microparticles enriched with rosemary by green-extraction techniques. Meat Sci. 2018, 146, 147-153. [CrossRef] [PubMed]

105. Lucas-González, R.; Rodán-Verdú, A.; Sayas-Barberá, E.; Fernández-López, J.; Pérez-Alvarez, J.A.; Viuda-Martos, M. Assessment of emulsion gels formulated with chestnut (Castanea sativa M.) flour and chia (Salvia hispanica L.) oil as partial fat replacers in pork burger formulation. J. Sci. Food Agric. 2020, 100, 1265-1273. [CrossRef] [PubMed]

106. Heck, R.T.; Saldaña, E.; Lorenzo, J.M.; Correa, L.P.; Fagundes, M.B.; Cichoski, A.J.; de Menezes, C.R.; Wagner, R.; Campagnol, P.C.B. Hydrogelled emulsion from chia and linseed oils: A promising strategy to produce low-fat burgers with a healthier lipid profile. Meat Sci. 2019, 156, 174-182. [CrossRef]

107. de Carvalho, F.A.L.; Lorenzo, J.M.; Pateiro, M.; Bermúdez, R.; Purriños, L.; Trindade, M.A. Effect of guarana (Paullinia cupana) seed and pitanga (Eugenia uniflora L.) leaf extracts on lamb burgers with fat replacement by chia oil emulsion during shelf life storage at $2{ }^{\circ} \mathrm{C}$. Food Res. Int. 2019, 125, 108554. [CrossRef] [PubMed]

108. Shokry, A.M. The usage of quinoa flour as a potential ingredient in production of meat burger with functional properties. Middle East J. Appl. Sci. 2016, 6, 1128-1137.

109. Özer, C.O.; Seçen, S.M. Effects of quinoa flour on lipid and protein oxidation in raw and cooked beef burger during long term frozen storage. Food Sci. Technol. 2018, 38, 221-227. [CrossRef] 
110. Baioumy, A.A.; Bobreneva, I.V.; Tvorogova, A.A.; Shobanova, T.V. Possibility of using quinoa seeds (Chenopodium quinoa) in meat products and its impact on nutritional and organoleptic characteristics. Biosci. Res. 2018, 15, 3307-3315.

111. Bagdatli, A. The influence of quinoa (Chenopodium quinoa Willd.) flour on the physicochemical, textural and sensorial properties of beef meatball. Ital. J. Food Sci. 2018, 30, 280-288.

112. Pintado, T.; Herrero, A.M.; Jiménez-Colmenero, F.; Pasqualin-Cavalheiro, C.; Ruiz-Capillas, C. Chia and oat emulsion gels as new animal fat replacers and healthy bioactive sources in fresh sausage formulation. Meat Sci. 2018, 135, 6-13. [CrossRef]

113. de Carvalho, F.A.L.; Munekata, P.E.S.; Pateiro, M.; Campagnol, P.C.B.; Domínguez, R.; Trindade, M.A.; Lorenzo, J.M. Effect of replacing backfat with vegetable oils during the shelf-life of cooked lamb sausages. LWT-Food Sci. Technol. 2020, 122, 109052. [CrossRef]

114. Barros, J.C.; Munekata, P.E.S.; Pires, M.A.; Rodrigues, I.; Andaloussi, O.S.; Rodrigues, C.E.; Trindade, M.A. Omega-3- and fibre-enriched chicken nuggets by replacement of chicken skin with chia (Salvia hispanica $\mathrm{L}$ ) flour. LWT-Food Sci. Technol. 2018, 90, 283-289. [CrossRef]

115. Verma, A.K.; Rakjumar, V.; Kumar, S. Effect of amaranth and quinoa seed flour on rheological and physicochemical properties of goat meat nuggets. J. Food Sci. Technol. 2019, 56, 5027-5035. [CrossRef] [PubMed]

116. Pires, M.A.; Barros, J.C.; Rodrigues, I.; Munekata, P.E.S.; Trindade, M.A. Improving the lipid profile of bologna type sausages with Echium (Echium plantagineum L.) oil and chia (Salvia hispanica L.) flour. LWT Food Sci. Technol. 2020, 119, 108907. [CrossRef]

117. de Souza-Paglarini, C.; de Figueiredo-Furtado, G.; Honório, A.R.; Mokarzel, L.; da Silva-Vidal, V.A.; Badan-Ribeiro, A.P.; Lopes Cunha, R.; Rodrigues-Pollonio, M.A. Functional emulsion gels as pork back fat replacers in Bologna sausage. Food Struct. 2019, 20, 100105. [CrossRef]

118. Pellegrini, M.; Lucas-González, R.; Sayas-Barberá, E.; Fernández-López, J.; Pérez-Alvarez, J.A.; Viuda-Martos, M. Quinoa (Chenopodium quinoa Willd) paste as partial fat replacer in the development of reduced fat cooked meat product type pâté: Effect on quality and safety. CyTA-J. Food 2018, 16, 1079-1088. [CrossRef]

119. Fernández-Diez, A.; Caro, I.; Castro, A.; Salvá, B.K.; Ramos, D.D.; Mateo, J. Partial fat replacement by boiled quinoa on the quality characteristics of a dry-cured sausage. J. Food Sci. 2016, 81, C1891-C1898.

120. Fernández-López, J.; Lucas-González, R.; Viuda-Martos, M.; Sayas-Barberá, M.E.; Navarro, C.; Haros, C.M.; Pérez-Alvarez, J.A. Chia (Salvia hispánica L.) products as ingredients for reformulating frankfurters: Effects on quality properties and shelf-life. Meat Sci. 2019, 156, 139-145. [CrossRef]

121. Scapin, G.; Schimdt, M.M.; Prestes, R.C.; Ferreira, S.; Silva, A.F.C.; da Rosa, C.S. Effect of extract of chia seed (Salvia hispanica) as an antioxidant in fresh pork sausage. Intern. Food Res. J. 2015, 3, 1195-1202.

122. Ayerza, R.; Coates, W. Ground chia seeds and chia oil effects on plasma lipids and fatty acids in the rat. Nutr. Res. 2005, 25, 995-1003. [CrossRef]

123. Cofrades, S.; Santos-López, J.A.; Freire, M.; Benedí, J.; Sánchez-Muniz, F.J. Oxidative stability of meat systems made with $\mathrm{W}_{1} / \mathrm{O} / \mathrm{W}_{2}$ emulsions prepared with hydroxytyrosol and chia oil as lipid phase. LWT Food Sci. Technol. 2014, 59, 941-947. [CrossRef]

124. Gorinstein, S.; Lojek, A.; Číž, M.; Pawelzik, E.; Delgado-Licon, E.; Medina, O.J.; Moreno, M.; Salas, I.A.; Goshew, I. Comparison of composition and antioxidant capacity of some cereals and pseudocereals. Intern. J. Food Sci. Technol. 2008, 43, 627-629. [CrossRef]

125. Haros, C.M.; Wronkowska, M. Pseudocereal dry and wet milling: Processes products and applications. In Pseudocereals: Chemistry and Technology; Haros, C.M., Schoenlechner, R., Eds.; John Wiley \& Sons, Ltd.: Oxfork, UK, 2017; pp. 163-183.

Publisher's Note: MDPI stays neutral with regard to jurisdictional claims in published maps and institutional affiliations. 